\title{
Ecological plasticity and commercial impact of invasive marbled crayfish populations in Madagascar
}

\author{
Ranja Andriantsoa' ${ }^{1}$, Sina Tönges ${ }^{1}$, Jörn Panteleit ${ }^{2}$, Kathrin Theissinger ${ }^{2}$, Vitor Coutinho Carneiro', \\ Jeanne Rasamy ${ }^{3}$ and Frank Lyko ${ }^{1 *}$ (D)
}

\begin{abstract}
Background: The marbled crayfish (Procambarus virginalis) is a monoclonal, parthenogenetically reproducing freshwater crayfish species that has formed multiple stable populations worldwide. Madagascar hosts a particularly large and rapidly expanding colony of marbled crayfish in a unique environment characterized by a very high degree of ecological diversity.

Results: Here we provide a detailed characterization of five marbled crayfish populations in Madagascar and their habitats. Our data show that the animals can tolerate a wide range of ecological parameters, consistent with their invasive potential. While we detected marbled crayfish in sympatry with endemic crayfish species, we found no evidence for the transmission of the crayfish plague pathogen, a potentially devastating oomycete. Furthermore, our results also suggest that marbled crayfish are active predators of the freshwater snails that function as intermediate hosts for human schistosomiasis. Finally, we document fishing, farming and market sales of marbled crayfish in Madagascar.
\end{abstract}

Conclusions: Our results provide a paradigm for the complex network of factors that promotes the invasive spread of marbled crayfish. The commercial value of the animals is likely to result in further anthropogenic distribution.

Keywords: Marbled crayfish, Madagascar, Ecology, Habitat diversity, Crayfish plague, Farming

\section{Background}

The marbled crayfish Procambarus virginalis [1] is the only known decapod crustacean that reproduces by obligate parthenogenesis [2]. While the precise origin of the animals remains to be identified, the first record of marbled crayfish is from the German aquarium trade in 1995 [1, 2], indicating a very recent evolutionary origin. Based on morphological characters and genetic data, the sexually reproducing slough crayfish from Florida, Procambarus fallax, has been identified as the most closely related species [2, 3]. Additional evidence strongly suggests that marbled crayfish separated from $P$. fallax by

\footnotetext{
*Correspondence: f.lyko@dkfz.de

${ }^{1}$ Division of Epigenetics, DKFZ-ZMBH Alliance, German Cancer Research Center (DKFZ), Im Neuenheimer Feld 580, 69120 Heidelberg, Germany

Full list of author information is available at the end of the article
}

major genetic changes $[4,5]$, which may have occurred as recently as 25 years ago. The combination of obligate parthenogenesis and very young evolutionary age has generated a population that can be considered a single genetic clone [6-8].

According to the Red Queen hypothesis [9], lack of genetic variation severely curtails the ability of a species to adapt and proliferate [10]. However, the genetically homogeneous marbled crayfish has been described as a successful invasive species in various countries [11-18]. This is exemplified by the situation in Madagascar, where marbled crayfish were first introduced around 2005 [11]. By 2008, the animals had already spread considerably and became widely recognized in the area around the capital city Antananarivo [11, 12]. In 2017, marbled crayfish had colonized an area of approximately $100,000 \mathrm{~km}^{2}$, stretching from the highland to the coast [8]. This area includes 
several habitats that are not inhabited by the relatively narrowly distributed native crayfish species of Madagascar $[19,20]$.

The invasiveness of marbled crayfish represents a key feature to define their overall impact [13, 21]. However, additional factors can contribute to this picture. For example, marbled crayfish may transmit the crayfish plague agent [22], the oomycete Aphanomyces astaci, which has eradicated major crayfish populations in Europe [23]. On the other hand, freshwater crayfish can also function as biocontrol agents for human diseases, such as schistosomiasis [24]. This is exemplified by their effects on the snail populations that function as intermediate hosts for Schistosoma flatworms and includes the direct predation of the snails and the consumption of aquatic plants that are used by the snails for shelter, as oviposition sites and as food [25]. Lastly, freshwater crayfish also represent an increasingly important source of nutritional protein for human consumption [26].

Despite their invasive spread, habitats of marbled crayfish have not been analyzed systematically yet. Madagascar is characterized by a high climate and habitat diversity. The broad range of aquatic ecosystems renders the island ideally suited to better understand marbled crayfish ecology. Furthermore, Madagascar hosts a unique and diverse flora and fauna, including seven endemic crayfish species from the genus Astacoides [19], which are potentially threatened by crayfish plague outbreaks. Finally, marbled crayfish have been spreading in Madagascar for the past 10 years [8], but their potential for human use has not been elucidated. Our study aims to provide a detailed description of the large population of marbled crayfish in Madagascar. Our results shed light on the animals' ability to colonize new environments, their impact on local freshwater ecosystems and their increasing commercial importance.

\section{Results}

After an initial field survey that determined the distribution area of marbled crayfish in Madagascar [8], we performed a more detailed follow-up analysis. We investigated five aquatic ecosystems consisting of three lentic and two lotic environments in four out of the five bioclimatic zones of Madagascar (Fig. 1a, Additional file 1). The lentic ecosystems include a randomly selected pond in the middle of a village on the east coast (Ampasimpotsy), a lake on the highlands in the center of a big city impacted by human activities (Ranomaimbo) and a rice field (Anjingilo) in a relatively isolated area in the south. Furthermore, two lotic habitats were included: a slow-flowing highland river located in the Ranomafana National Park rainforest (Andragnaroa) and a slow-flowing lowland river located near a large city in south-central
Madagascar (Ihosy). Sequencing of PCR amplicons from three randomly collected animals from each of the five sites showed complete identity with the marbled crayfish reference sequence (Fig. 1b), and thus provided genetic authentication for the populations analyzed in this study.

In total, we collected 6641 crayfishes and obtained data for 2458 animals (192-817 animals per site, Fig. 1c). Catch per hour results differed considerably between individual sites, ranging from 154 animals in Ihosy to $<20$ animals in Andragnaroa (Fig. 1d). These results suggest that population densities differ between the analyzed sites. Measurements established carapace lengths that were often between 10 and $35 \mathrm{~mm}$ and total lengths between 30 and $80 \mathrm{~mm}$ (Fig. 2). Animal weights usually ranged from 1 to $10 \mathrm{~g}$ (Fig. 2). Marbled crayfish were significantly ( $<<0.05$, Kruskal-Wallis one-way analysis of variance) larger and heavier in the Ihosy river as compared to the remaining sites (Fig. 2). The reasons for these differences remain to be established.

Subsequent analyses revealed remarkable differences for several fundamental ecological parameters. For example, while marbled crayfish were initially described to inhabit the central highland of Madagascar [11], the population in the Ampasimpotsy pond was located almost at sea level (Fig. 3a). In fact, we detected marbled crayfish at a wide range of altitudes (3-1491 m, Fig. 3b). Additional examples for the ability of marbled crayfish to colonize different habitats were provided by the Anjingilo rice fields (Fig. 4a) that are irrigated by thermal water and the Ranomaimbo lake located in the city center of Antsirabe (Fig. 4b). The water of Anjinglio is characterized by a particularly high temperature of $37^{\circ} \mathrm{C}$ and elevated Barium concentrations, which are characteristic of thermal water (Fig. 4c). The water of the Ranomaimbo lake was characterized by particularly high conductivity levels and a high concentration of dissolved solids (Fig. 4c), such as Natrium $(157 \mathrm{mg} / \mathrm{l})$ and Nitrate $(20 \mathrm{mg} / \mathrm{l})$. These values reflect the high levels of pollution that are often associated with urban settlements. Taken together, our findings suggest that marbled crayfish can tolerate substantial variation in ecological parameters.

To explore the potential impact of these populations, we first investigated their infection status with the crayfish plague pathogen $A$. astaci. Indeed, a previous study had suggested low levels of $A$. astaci in marbled crayfish populations from Germany [22]. We investigated 100 animals from the five previously mentioned sites and from Antananarivo, where marbled crayfish were first detected on Madagascar [11]. Quantitative PCR (Fig. 5a) indicated undetectable (agent level $\mathrm{A} 0$ and $\mathrm{A} 1$ ) or very low (A2) levels of $A$. astaci DNA for the large majority (96/100) of samples. Only four samples presented with somewhat higher levels (A3). However, confirmatory sequencing 

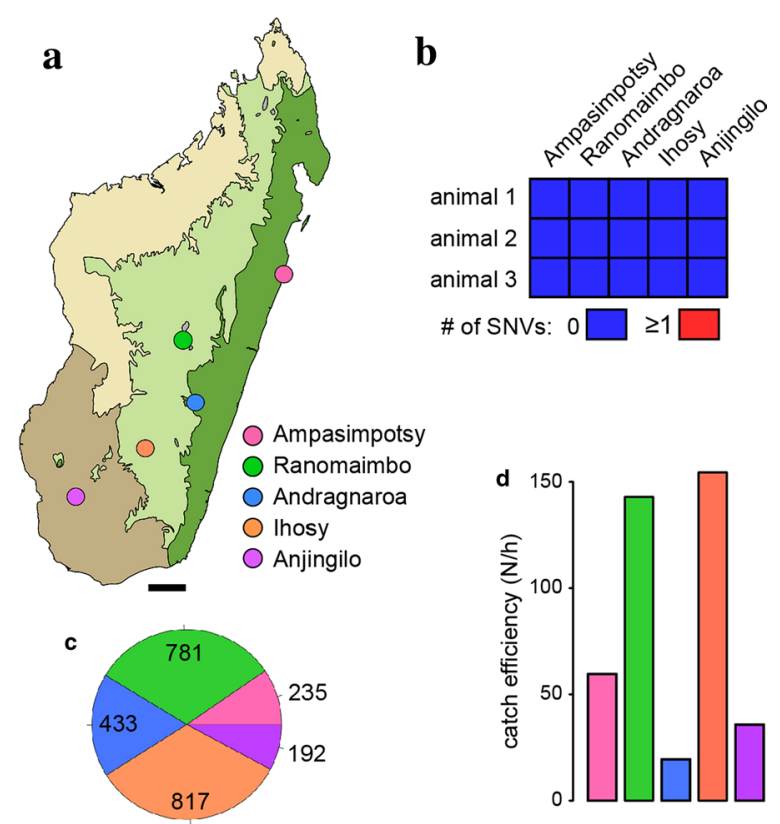

Fig. 1 Overview of the study. a Map of Madagascar (generated by the first author) indicating the location of the 5 selected sites. Bar: $100 \mathrm{~km}$. Area colors indicate bioclimates, see "Methods" for details. Dark green: humid, light green: sub-humid, grey: montane, beige: dry, brown: sub-arid. $\mathbf{b}$ Genetic authentication of 3 randomly selected animals per site. The number of single-nucleotide variants in the mitochondrial cytochrome B gene was 0 for all animals tested. c Numbers of animals that were analyzed at each site. $\mathbf{d}$ Catch efficiencies (number of catches for 2 persons per hour) for each site

and microsatellite analyses could not be carried out due to the low amounts of $A$. astaci DNA in the tissues. Notably, we also found marbled crayfish in natural habitats of two Astacoides species: in the Andragnaroa river, in sympatry with $A$. betsileoensis (Fig. $5 \mathrm{~b}$ ) and in a channel connected to a rice field in Sahavondronina, in sympatry with A. granulimanus. Marbled crayfish populations in those two locations have been known for at least 2 years, with no indications for crayfish plague outbreaks. Taken together, these results suggest that marbled crayfish do not trigger crayfish plague outbreaks in Madagascar.

We also noticed that the distribution area of marbled crayfish showed a strong overlap with the freshwater snail Biomphalaria pfeifferi, which acts as the main intermediate host of the parasitic flatworm Schistosoma mansoni in Madagascar [27, 28]. However, we could not find B. pfeifferi at the locations that we analyzed for marbled crayfish, suggesting possible predation. To confirm this possibility, we performed a laboratory experiment by placing snails of different sizes in laboratory boxes with a single marbled crayfish (Fig. 5c). After the first night, all $(\mathrm{N}=28)$ snails had been eaten by the crayfish, and only leftover shells (Fig. 5d) were found in the boxes. This suggests that marbled crayfish can act as effective predators of B. pfeifferi.

Finally, we also addressed the emerging role of marbled crayfish as a food for human consumption. Marbled crayfish can be easily caught in rivers and ponds using traditional Malagasy fishing tools (Fig. 6a). Furthermore, the animals are also farmed in larger quantities on rice fields (Fig. 6b). For commercial distribution, $60-80 \mathrm{~kg}$ of live animals are packed in large bags (Fig. 6c) and then sold to consumers and/or local vendors. The measurement of 200 arbitrarily sampled animals from commercially distributed marbled crayfish established a median total length of $57 \mathrm{~mm}$ (Fig. 6d) and a median weight of $4.8 \mathrm{~g}$ (Fig. 6e), thus illustrating the commercial relevance of relatively small animals. Marbled crayfish currently represent an important component of the animal protein supply on local markets in all areas that were analyzed in this study and are being sold both as live animals (Fig. 6f) and as boiled and processed tail meat (Fig. 6g). Prices ranged from 500 to 1500 MGA per $\mathrm{kg}$ for live animals to 8000 MGA per kg for tail meat (Fig. 6g), which is comparable to the price of rice (approximately 2000 MGA per kg, Fig. 6g). Popular marbled crayfish foods include deepfried beignets and rice with marbled crayfish in tomato sauce (Fig. 6h). The increasing acceptance and popularity of marbled crayfish foods in Madagascar is likely to further increase their commercial demand and intentional propagation.

\section{Discussion}

Crayfish distribution and density is often influenced by specific habitat requirements $[29,30]$. However, some crayfish species, such as Procambarus clarkii, are known to tolerate a broader range of environmental factors, such as water temperature, oxygen level and/or aquatic ecosystem type [31,32]. Another example is the mother species of the marbled crayfish, $P$. fallax, which has been shown to inhabit aquatic ecosystems with various trophic levels, $\mathrm{pH}$ levels and water temperatures (summarized in [33]). Our findings are consistent with the notion that the marbled crayfish can tolerate a broad range of ecological parameters [33]. Furthermore, its successful colonization of diverse habitats in Madagascar clearly suggests high plasticity towards physico-chemical parameters and diverse biocenoses. Additionally, we have shown that altitude, which is closely linked to the diverse bioclimatic zones in Madagascar, has a negligible impact on marbled crayfish distribution. These findings significantly expand the suitable habitat of the global marbled crayfish population [21].

Adaptation to new environments is often explained by the selection of genetic variants. Interestingly, however, marbled crayfish are genetically identical, which suggests 


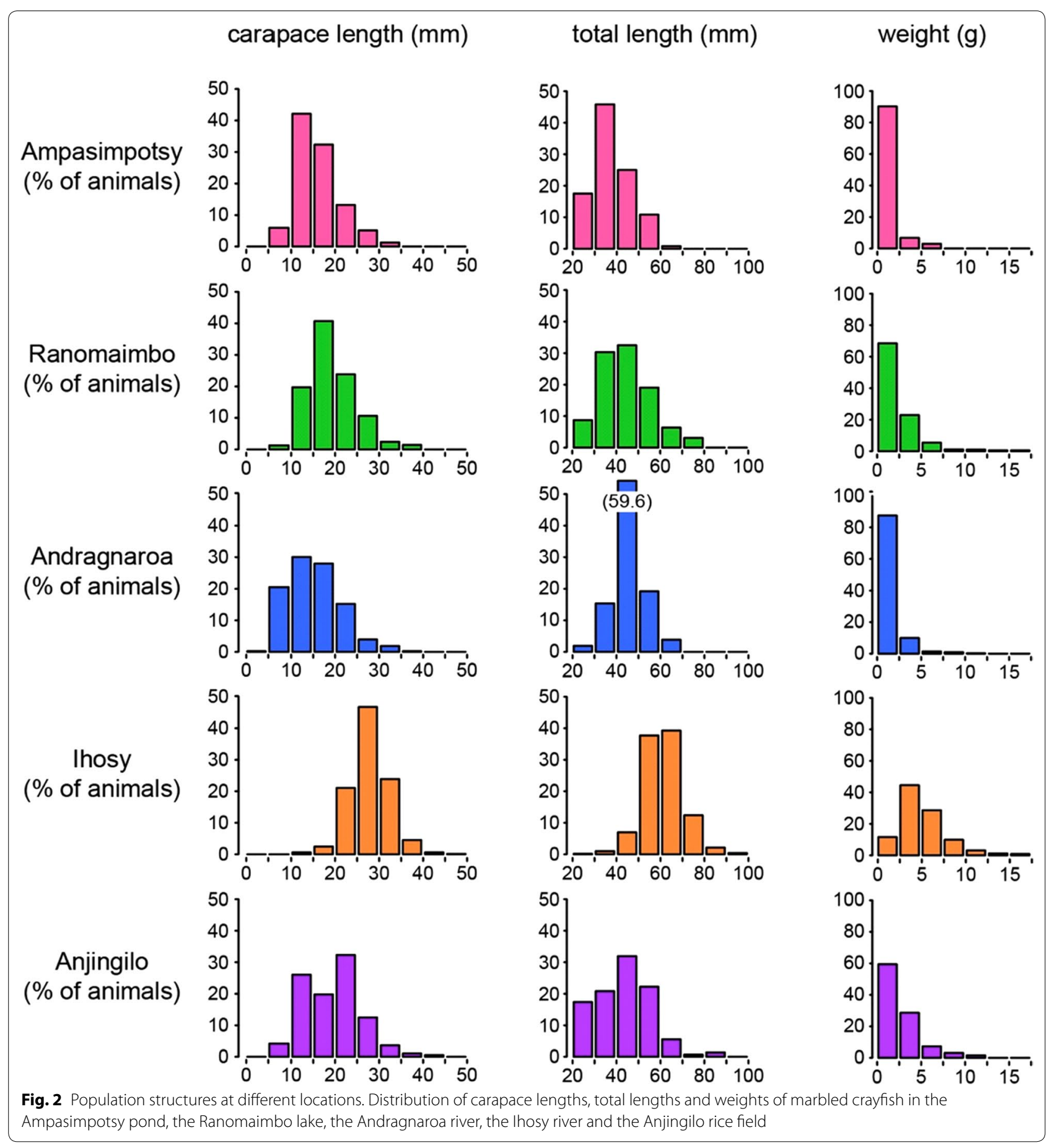

a central role of epigenetic mechanisms, such as DNA methylation, in their adaptation [8]. A recent study has provided a detailed characterization of DNA methylation patterns in marbled crayfish [34]. Interestingly, more than 2000 genes were found to be less methylated in marbled crayfish than in P. fallax, which was associated with more variable gene expression in marbled crayfish
[34]. Gene expression variability has been suggested to facilitate adaptation in corals [35], but a functional role of DNA methylation in the adaptation of marbled crayfish remains to be shown.

Our study provides further insight into the impact of marbled crayfish in Madagascar. Traditionally, the impact of invasive crayfish species is defined by their disruptive 


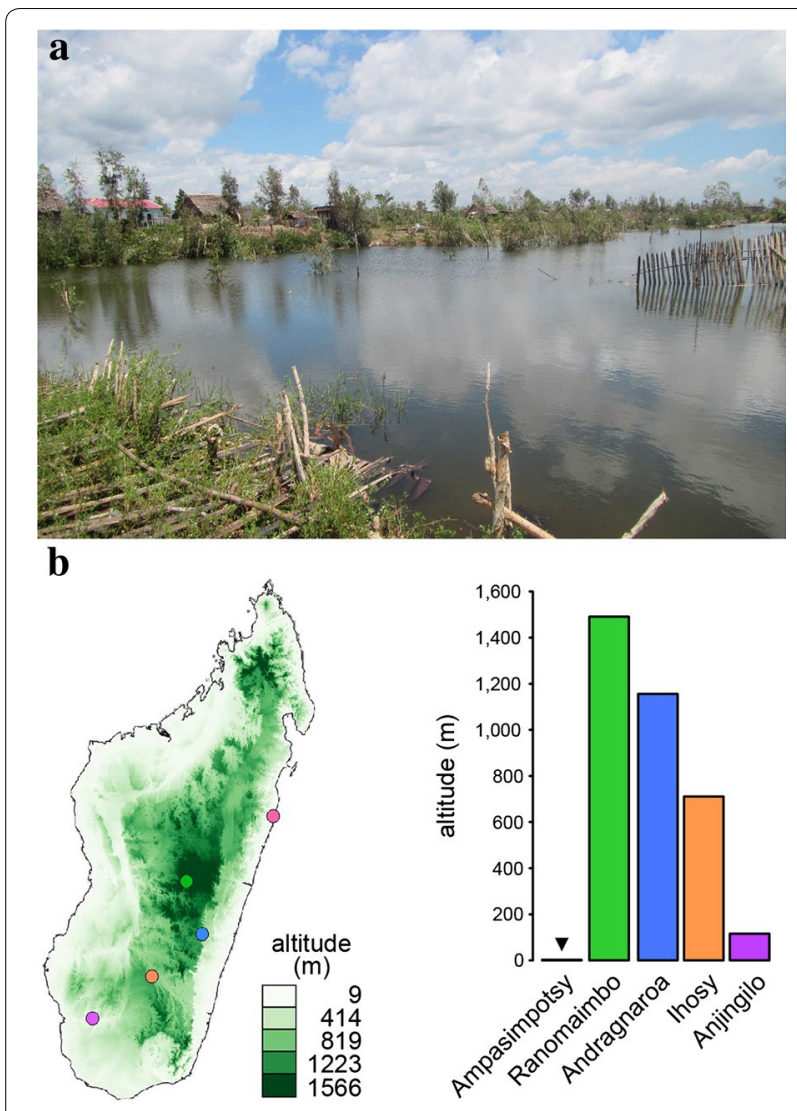

Fig. 3 Marbled crayfish populations inhabit ecological niches at different altitudes. a Picture of the Ampasimpotsy coastal pond, which is located $3 \mathrm{~m}$ above sea level. b Map of altitudinal gradients of Madagascar and altitudes of the 5 selected sites. Picture and map were produced by the first author

effects on ecosystems and their capacity to transmit pathogens to naive hosts [36]. Indeed, the invasive spread of infected marbled crayfish could potentially have catastrophic consequences on the seven endemic freshwater crayfish species of Madagascar. Encouragingly, we found no evidence for crayfish plague outbreaks. A. astaci levels were below the limit of detection in 96 of the 100 samples analyzed, with the remaining four samples showing very low levels of DNA that could not be confirmed by sequencing. Also, we have observed two of the seven endemic crayfish species in sympatry with marbled crayfish, and with no symptoms of the crayfish plague. These findings suggest that either the marbled crayfish in Madagascar do not transmit the crayfish plague agent or that the (as yet unidentified) $A$. astaci strain is not very virulent. It is also possible that Astacoides is resistant to the disease, similar the American crayfish species and the European freshwater crayfish Autropotamobius pallipes
$[37,38]$. It will be important to clarify the infection status of Astacoides in future studies.

Our results also shed light on the potential use of marbled crayfish as a biocontrol agent against B. pfeifferi, which functions as intermediate host of Schistosoma flatworms in Madagascar and other African countries [27, 39]. Schistosomiasis remains a major public health problem in Madagascar with infection rates exceeding $50 \%$ of the total population [40-42]. Several freshwater crustaceans have been suggested as biocontrol agents of mollusk intermediate hosts to limit or reduce schistosomiasis infestation [24, 43-45]. However, the distribution ranges of these species and $B$. pfeifferi show little overlap on Madagascar. In contrast, marbled crayfish are widely distributed in Madagascar and it will be important to analyze their impact on the local presence and population densities of $B$. pfeifferi and the prevalence of schistosomiasis.

After the first scientific survey in Madagascar in 20072008 identified marbled crayfish as an ecological threat [11], the Ministry of Agriculture, Livestock and Fisheries issued legislation to prohibit the transportation of live marbled crayfish [46]. In addition, it was claimed that marbled crayfish consumption might be unhealthy for humans. Together, these factors initially restricted the commercial distribution of the animals. However, freshwater crayfish are a popular food in Madagascar and the endemic species have been harvested and consumed in large quantities for a long time. While their fishing and farming is severely limited by their specific habitat requirements and slow growth [19], marbled crayfish can grow quickly in diverse aquatic ecosystems. Furthermore, marbled crayfish are easy to stock, as a single animal can give rise to a new population. As such, they represent an attractive source of income and a cheap alternative for nutritional protein. By now, marbled crayfish have become an abundant and popular food in their distribution area in Madagascar. We expect that this popularity will further increase their spread, similar to other invasive species that have extended their distribution range through commercial networks [47].

\section{Conclusions}

The marbled crayfish is a newly emerging invasive species, but very little is known about its ecological interactions. Our study provides the first detailed description of habitats that were successfully colonized by marbled crayfish populations in Madagascar. Our findings suggest a substantial habitat diversity and thus convincingly establish the ecological plasticity of the animals. Our results also provide answers for additional, important questions. For example, we found no evidence for the transmission of the crayfish plague pathogen by marbled 

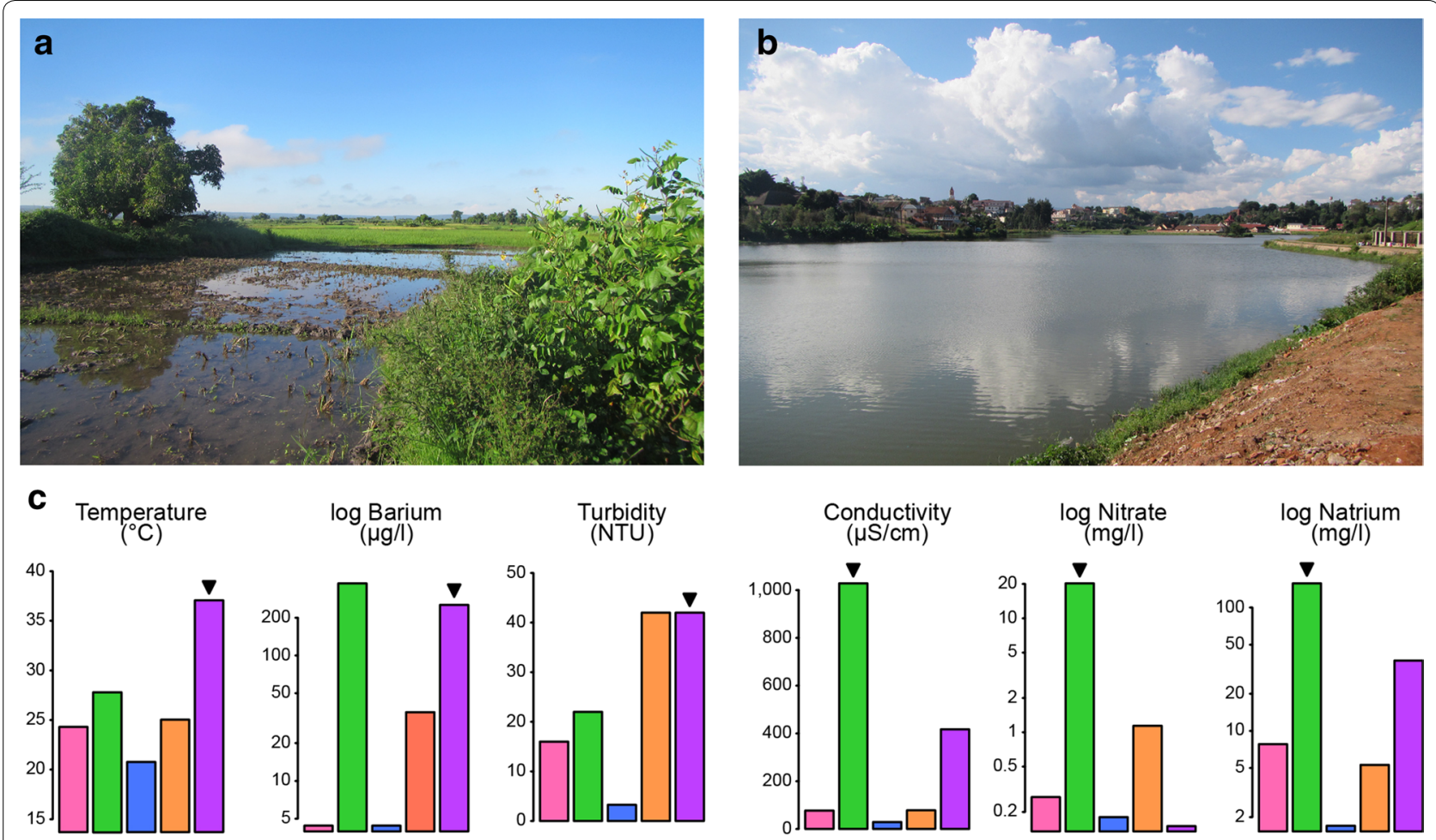

Fig. 4 Marbled crayfish population habitats. a Picture of the Anjingilo rice field and $\mathbf{b}$ the Ranomaimbo lake. $\mathbf{c}$ Specific water parameters of the five habitats analyzed. All pictures were produced by the first author
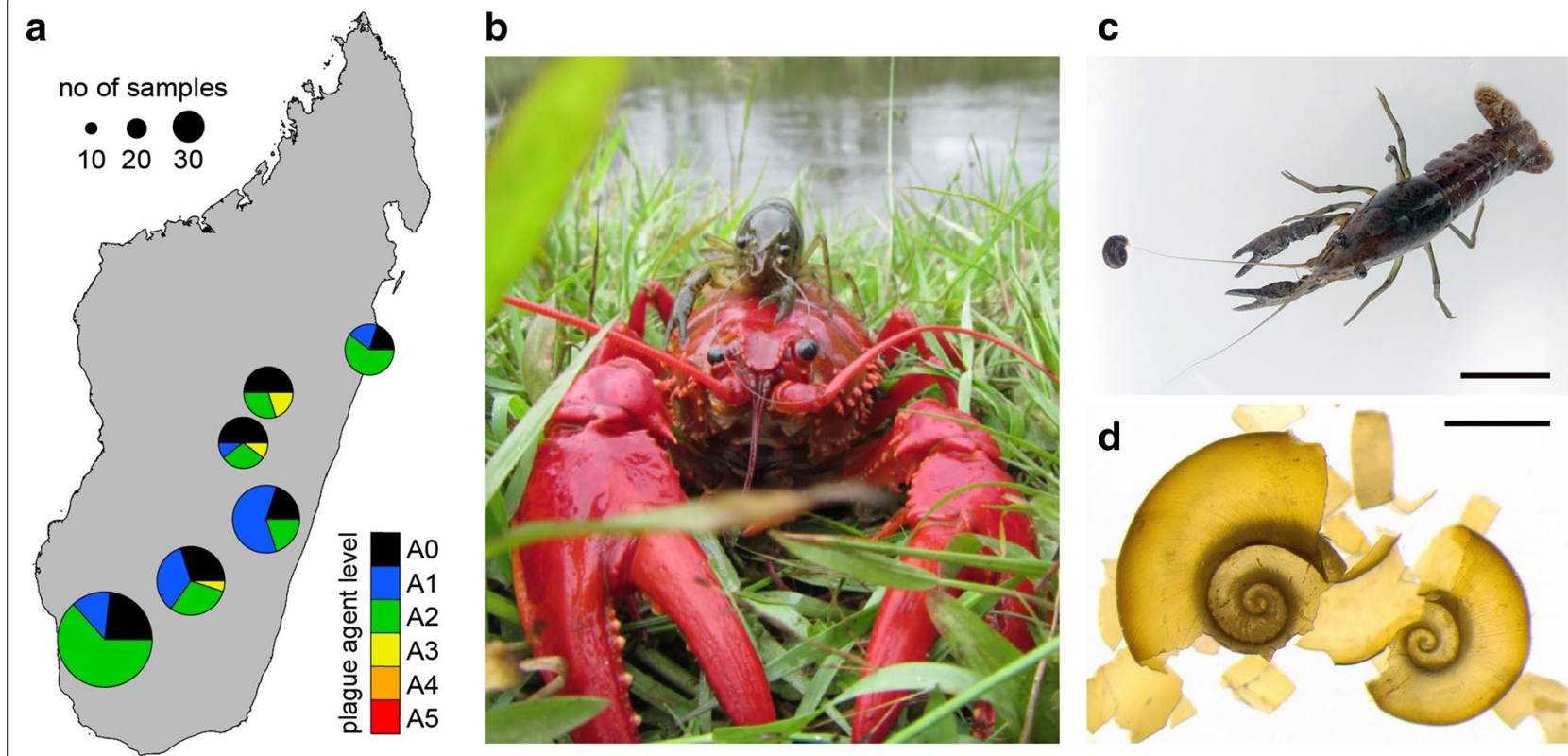

Fig. 5 Biological impact of marbled crayfish on Madagascar. a Real-time PCR detection of the crayfish plague agent Aphanomyces astacii in animals that were collected in various locations in Madagascar. Numbers of animals analyzed per site are indicated by circle size (small $=10$, intermediate $=20$, large $=30$ ). Agent levels are indicated by section colors. $\mathbf{b}$ Sympatry of marbled crayfish and Astacoides betsileoensis in the Andragnaroa river. c Laboratory experiment to test the predation of Biomphalaria pfeifferi snails by marbled crayfish. Bar: $2 \mathrm{~cm}$. $\mathbf{d}$ Leftover B. pfeifferi shells, found after overnight co-housing with marbled crayfish. Bar: $2 \mathrm{~mm}$. Map and pictures were produced by the first author 

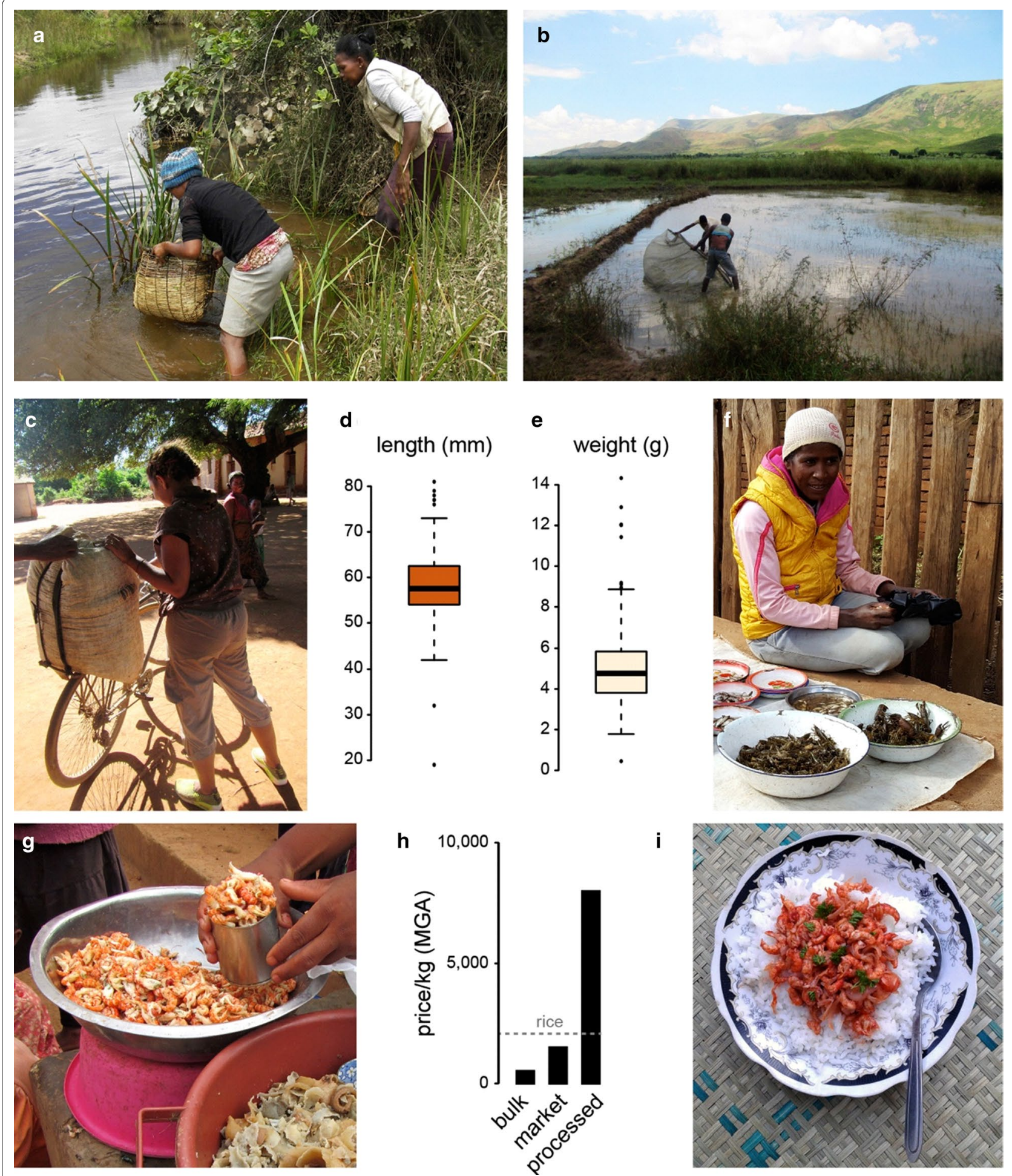

Fig. 6 Commercial impact of marbled crayfish on Madagascar. a Marbled crayfish fishing in the Andragnaroa river, using the traditional Malagasy fishing tool ("tandroho"). b Farming on marbled crayfish on rice fields in Ihosy. c Commercial distribution of live marbled crayfish in large bags. d Length and e weight of 200 arbitrarily sampled animals from a commercial distribution bag. $\mathbf{f}$ Market sale of live marbled crayfish in Antsirabe. $\mathbf{g}$ Market sale of processed marbled crayfish tail meat in Antananarivo. $\mathbf{h}$ Representative prices (in MGA/kg) for various quantities and qualities of marbled crayfish. $\mathbf{i}$ Typical marbled crayfish-based food: rice with marbled crayfish in tomato sauce. All pictures were produced by the first author 
crayfish. We also show that the animals are active predators of the intermediate hosts for human schistosomiasis. Finally, we provide the first documentation for the commercial exploitation of marbled crayfish for human consumption. Altogether, our study thus identifies key factors for the ecological assessment of this new invasive species.

\section{Methods}

\section{Field work}

The study was carried out from October 2017 to March 2018 in Madagascar. Details about collection sites are provided in Additional file 1. Pictures of habitats were taken using a Canon PowerShot D30 digital camera or a Samsung Galaxy S6 camera. For each habitat, we chose sampling stations of 20 to $150 \mathrm{~cm}$ depth and 50 to $1000 \mathrm{~cm}$ width. Collections were done in the morning from 8:00 to 11:00 for 5 to 7 days. One effort unit is defined as 2 persons per site per hour on total surface area of $100 \mathrm{~m}^{2}$ represented either by a transect or a quadrat. Crayfish were caught without release, either by the traditional fishing tool "tandroho" $(50 \mathrm{~cm} \times 30 \mathrm{~cm} \times 30 \mathrm{~cm})$ or with a net $(200 \times 400 \mathrm{~cm})$ or manually in burrows. Carapace length and total length were measured using a manual caliper and weight was recorded using a portable scale with $0.1 \mathrm{~g}$ precision. Female sex was morphologically confirmed by the presence of the gonopores on the base of the third pair of legs and the ovaries under the carapace. Abdominal musculature samples from three animals per site were preserved in ethanol for genotyping, while soft cuticles, uropods and legs were preserved for the molecular detection of the crayfish plague agent Aphanomyces astaci. After data collection, all animals were sacrificed according to current Malagasy legislation, which prohibits the release or live transportation of marbled crayfish. Statistical comparisons of body size structure among the sites were performed by the nonparametric test of Kruskal-Wallis. All maps were drawn with QGIS (Open Source Geospatial Foundation Project) version 2.18.7. The shapefiles used to draw the 5 bioclimatic boundaries [48] were downloaded from http:// www.mobot.org/MOBOT/Research/madagascar/gazet teer/. Madagascar boundaries and altitudinal gradients shapefiles were downloaded from the Free Spatial Data in DIVA-GIS (http://www.diva-gis.org).

\section{Habitat parameters}

For each sampling site, bottom sediments (mud, clay, sand) were visually identified and water temperature was recorded with a multiparameter device (Hanna Instruments HI991300) $10 \mathrm{~cm}$ below the surface between 8:00 and 10:00 in the morning. The same device was used to record the conductivity and the $\mathrm{pH}$ with a calibration at
$25{ }^{\circ} \mathrm{C}$. Neighboring vegetation and animals co-collected in the fishing tools were recorded for each site (Additional file 1). Finally, water samples were collected at each site, and stored in a cold and dark place. Barium, Natrium and Nitrate levels were determined by RaiffeisenLaborservice (Ormont, Germany).

\section{Genetic authentication of marbled crayfish}

Genomic DNA was isolated and purified from $100 \mathrm{mg}$ abdominal musculature using a Tissue Ruptor (Qiagen), followed by proteinase $\mathrm{K}$ digestion and ethanol precipitation. Genotyping was performed by sequencing of a PCR amplicon from the mitochondrial cytochrome $b$ gene, as described before [8]. The complete sequencing results are provided in Additional file 2.

\section{Crayfish plague analysis}

The crayfish tissue samples were dried and pulverized with a Tissue Lyser II (Qiagen, Germany). DNA was extracted with the E.Z.N.A. Insect DNA Kit (omega biotek, USA) according to the manufacturer's instructions. The qPCR protocol to detect $A$. astaci was identical to the one used in [49] with an increased annealing temperature and decreased annealing time [50]. The results of the qPCR are categorized in semi-quantitative levels called agent levels, with increasing amounts of $A$. astaci DNA. Agent levels A0 and A1 are generally considered negative, while $\mathrm{A} 3$ to $\mathrm{A} 7$ are considered positive (A2 is considered ambiguous).

\section{B. pfeifferi predation}

Biomphalaria pfeifferi snails $(\mathrm{N}=28,1-4 \mathrm{~mm}$, a kind gift from Nelia Luviano and Christoph Grunau, University of Perpignan) were divided into seven groups of four and placed in closed laboratory boxes with a single marbled crayfish (TL 6-8 cm) that had been starved for 24 to $48 \mathrm{~h}$. The boxes were checked every hour, left unattended overnight from 18:00, and checked again on the next morning at 9:00. Representative images were acquired on a Stereomicroscope (Olympus SZX10).

\section{Market and trade investigations}

Marbled crayfish value on the market was evaluated among three main groups: chiefs of locations $(n=11)$, fishermen and/or crayfish collectors $(n=27)$ and local vendors $(n=17)$. Chiefs were interviewed first to evaluate the status of marbled crayfish in the area, such as fishing activities, locations of populations and markets. They also identified local collaborators (e.g. fishermen and/or crayfish collectors) that could provide further information about crayfish locations, farming and prices on the markets. Local vendors were interviewed about the main 
consumers and the prices of live and processed marbled crayfish.

\section{Additional files}

Additional file 1. Detailed descriptions of marbled crayfish habitats, including coordinates.

Additional file 2. DNA sequencing data.

\section{Authors' contributions}

RA organized field work, collected field data, carried out the analyses and drafted the manuscript. ST provided water analyses. JP provided crayfish plague analyses. KT and VCC provided input on analyses and on the manuscript. JR co-conceived the study and collected field data. FL co-conceived the study, coordinated the study and wrote the manuscript. All authors read and approved the final manuscript.

\section{Author details}

${ }^{1}$ Division of Epigenetics, DKFZ-ZMBH Alliance, German Cancer Research Center (DKFZ), Im Neuenheimer Feld 580, 69120 Heidelberg, Germany. ${ }^{2}$ Institute for Environmental Sciences, University of Koblenz-Landau, Fortstrasse 7, 76829 Landau, Germany. ${ }^{3}$ Mention Zoologie et Biodiversité Animale, Université d'Antananarivo, BP906, 101 Antananarivo, Madagascar.

\section{Acknowledgements}

We thank Nelia Luviano and Christoph Grunau (University of Perpignan) for the generous gift of B. pfeifferi. We also thank Najmusseher Abdul Shakoor Ghani for her assistance with crayfish plague analyses.

\section{Competing interests}

The authors declare that they have no competing interests.

\section{Availability of data and materials}

Detailed descriptions of marbled crayfish habitats, including coordinates, are provided in Additional file 1. Sequencing data is provided in Additional file 2.

\section{Consent for publication}

Not applicable.

\section{Ethics approval and consent to participate}

All crayfish specimens were collected in accordance with the conditions set by the Ministry of Ecology, Environment and Forest of Antananarivo, Madagascar (research permits Nos. 239/17/MEEF/SG/DGF/DSAP/SCB.Re, 017/18/MEEF/ SG/DGF/DSAP/SCB.Re, 045/18/MEEF/SG/DGF/DSAP/SCB.Re and 056/18/ MEEF/SG/DGF/DSAP/SCB.Re).

\section{Funding}

VCC is supported by a postdoctoral fellowship from CellNetworks. The funding body had no role in the design of the study, the collection, analysis, or interpretation of data or in writing the manuscript.

\section{Publisher's Note}

Springer Nature remains neutral with regard to jurisdictional claims in published maps and institutional affiliations.

Received: 28 October 2018 Accepted: 29 January 2019

Published online: 06 February 2019

\section{References}

1. Lyko F. The marbled crayfish (Decapoda: Cambaridae) represents an independent new species. Zootaxa. 2017;4363:544-52.
2. Scholtz G, Braband A, Tolley L, Reimann A, Mittmann B, Lukhaup C, Steuerwald F, Vogt G. Ecology: parthenogenesis in an outsider crayfish. Nature. 2003:421(6925):806.

3. Martin P, Dorn NJ, Kawai T, van der Heiden C, Scholtz G. The enigmatic Marmorkrebs (marbled crayfish) is the parthenogenetic form of Procambarus fallax (Hagen, 1870). Contrib Zool. 2010;79:107-18.

4. Vogt G, Falckenhayn C, Schrimpf A, Schmid K, Hanna K, Panteleit J, Helm M, Schulz R, Lyko F. The marbled crayfish as a paradigm for saltational speciation by autopolyploidy and parthenogenesis in animals. Biol Open. 2015;4(11):1583-94.

5. Martin P, Thonagel S, Scholtz G. The parthenogenetic Marmorkrebs (Malacostraca: Decapoda: Cambaridae) is a triploid organism. J Zool Syst Evol Res. 2016:54:13-21.

6. Martin P, Kohlmann K, Scholtz G. The parthenogenetic Marmorkrebs (marbled crayfish) produces genetically uniform offspring. Naturwissenschaften. 2007;94(10):843-6.

7. Vogt G, Huber M, Thiemann M, van den Boogaart G, Schmitz OJ, Schubart CD. Production of different phenotypes from the same genotype in the same environment by developmental variation. J Exp Biol. 2008;211(Pt 4):510-23.

8. Gutekunst J, Andriantsoa R, Falckenhayn C, Hanna K, Stein W, Rasamy JR, Lyko F. Clonal genome evolution and rapid invasive spread of the marbled crayfish. Nat Ecol Evol. 2018;2:567-73.

9. Van Valen L. A new evolutionary law. Evol Theory. 1973;1:1-30.

10. Bell $\mathrm{G}$. The masterpiece of nature: the evolution and genetics of sexuality. Berkeley: University of California Press; 1982.

11. Jones JPG, Rasamy JR, Harvey A, Toon A, Oidtmann B, Randrianarison MH, Raminosoa N, Ravoahangimalala OR. The perfect invader: a parthenogenic crayfish poses a new threat to Madagascar's freshwater biodiversity. Biol Invasions. 2009;11:1475-82.

12. Kawai T, Scholtz G, Morioka S, Ramanamandimby F, Lukhaup C, Hanamura Y. Parthenogenetic alien crayfish (Decapoda: Cambaridae) spreading in Madagascar. J Crust Biol. 2009;29:562-7.

13. Chucholl C, Morawetz K, Groß H. The clones are coming-strong increase in Marmorkrebs Procambarus fallax (Hagen, 1870) $\mathrm{f}$. virginalis records from Europe. Aquat Invasions. 2012;7:511-9.

14. Bohman P, Edsman L, Martin P, Scholtz G. The first Marmorkrebs (Decapoda: Astacida: Cambaridae) in Scandinavia. Bioinvasions Rec. 2013;2:227-32

15. Patoka J, Buric M, Kolar V, Blaha M, Petrtyl M, Franta P, Tropek R, Kalous L, Petrusek A, Kouba A. Predictions of marbled crayfish establishment in conurbations fulfilled: evidences from the Czech Republic. Biologia. 2016;71:1380-5.

16. Lokkos A, Muller T, Kovacs K, Varkonyi L, Specziar A, Martin P. The alien, parthenogenetic marbled crayfish (Decapoda: Cambaridae) is entering Kis-Balaton (Hungary), one of Europe's most important wetland biotopes. Knowl Manag Aquat Ecosyst. 2016;417:16.

17. Liptak B, Mrugala A, Pekarik L, Mutkovic A, Grula D, Petrusek A, Kouba A. Expansion of the marbled crayfish in Slovakia: beginning of an invasion in the Danube catchment? J Limnol. 2016;75:305-12.

18. Novitsky RA, Son MO. The first records of Marmorkrebs [Procambarus fallax (Hagen, 1870) $f$. virginalis] (Crustacea, Decapoda, Cambaridae) in Ukraine. Ecol Montenegrina. 2016:5:44-6.

19. Jones JPG, Andriahajaina FB, Hockley NJ, Crandall KA, Ravoahangimalala OR. The ecology and conservation status of Madagascar's endemic freshwater crayfish (Parastacidae; Astacoides). Freshwater Biol. 2007:52:1820-33.

20. Toon A, Pérez-Lozada M, Schweizter CE, Feldman RM, Carlson M, Crandall KA. Gondwanan radiation of the Southern Hemisphere crayfishes (Decapoda: Parastacidae): evidence from fossils and molecules. J Biogeogr. 2010;37:2275-90.

21. Feria TP, Faulkes Z. Forecasting the distribution of Marmorkrebs, a parthenogenetic crayfish with high invasive potential, in Madagascar, Europe, and North America. Aquat Invasions. 2011;6:55-67.

22. Keller NS, Pfeiffer M, Roessink I, Schulz R, Schrimpf A. First evidence of crayfish plague agent in populations of the marbled crayfish (Procambarus fallax forma virginalis). Knowl Manag Aquat Ecosyst. 2014;414:15.

23. Svoboda J, Mrugala A, Kozubikova-Balcarova E, Petrusek A. Hosts and transmission of the crayfish plague pathogen Aphanomyces astaci: a review. J Fish Dis. 2017;40(1):127-40. 
24. Mkoji GM, Hofkin BV, Kuris AM, Stewart-Oaten A, Mungai BN, Kihara JH, Mungai F, Yundu J, Mbui J, Rashid JR, et al. Impact of the crayfish Procambarus clarkii on Schistosoma haematobium transmission in Kenya. Am J Trop Med Hyg. 1999;61(5):751-9.

25. Hofkin BV, Koech DK, Oumaj J, Loker ES. The North American crayfish Procambarus clarkii and the biological control of schistosome-transmitting snails in Kenya: laboratory and field investigations. Biol Control. 1991;1(3):183-7.

26. Fisheries statistical database. Global aquaculture production (fisheries global information system, online query). http://www.fao.org/fishery/stati stics/global-aquaculture-production/en. Accessed 5 Oct 2018.

27. Charbonnel N, Angers B, Rasatavonjizay R, Bremond P, Debain C, Jarne P. The influence of mating system, demography, parasites and colonization on the population structure of Biomphalaria pfeifferi in Madagascar. Mol Ecol. 2002;11(11):2213-28.

28. Morgan JA, Dejong RJ, Adeoye GO, Ansa ED, Barbosa CS, Bremond P, Cesari IM, Charbonnel N, Correa LR, Coulibaly G, et al. Origin and diversification of the human parasite Schistosoma mansoni. Mol Ecol. 2005;14(12):3889-902.

29. Wooster D, Snyder JL, Madsen A. Environmental correlates of signal crayfish, Pacifastacus leniusculus (Dana, 1852), density and size at two spatial scales in its native range. J Crust Biol. 2012;32:741-52.

30. Vedia I, Galicia D, Baquero E, Oscoz J, Miranda R. Environmental factors influencing the distribution and abundance of the introduced signal crayfish in the north of Iberian Peninsula. Mar Freshw Res. 2017;68(5):900-8.

31. Huner JV, Barr JE. Red Swamp Crawfish: biology and exploitation. 3rd ed. Baton Rouge: Lousiana Sea Grant College Program, Center for Wetland Resources, Louisiana State University; 1991.

32. Gherardi F. Crayfish invading Europe: the case study of Procambarus clarkii. Aquat Ecosyst. 2006:416:1-15.

33. Vogt G, Dorn NJ, Pfeiffer M, Lukhaup C, Williams BW, Schulz R, Schrimpf A. In-depth investigation of the species problem and taxonomic status of marbled crayfish, the first asexual decapod crustacean. bioRxiv. 2018.

34. Gatzmann F, Falckenhayn C, Gutekunst J, Hanna K, Raddatz G, Carneiro VC, Lyko F. The methylome of the marbled crayfish links gene body methylation to stable expression of poorly accessible genes. Epigenet Chromatin. 2018;11:57.

35. Kenkel CD, Matz MV. Gene expression plasticity as a mechanism of coral adaptation to a variable environment. Nat Ecol Evol. 2016;1(1):14

36. Longshaw M. Diseases of crayfish: a review. J Invertebr Pathol. 2011;106(1):54-70.

37. Unestam T. On the host range and origin of the crayfish plague fungus. Rep Inst Freshw Res Drottningholm. 1972;52:192-8.
38. Martin-Torrijos L, Campos Llach M, Pou-Rovira Q, Dieguez-Uribeondo J. Resistance to the crayfish plague, Aphanomyces astaci (Oomycota) in the endangered freshwater crayfish species, Austropotamobius pallipes. PLoS ONE. 2017;12(7):e0181226.

39. Pfluger W. Ecological studies in Madagascar of Biomphalaria pfeifferi, intermediate host of Schistosoma mansoni. 2. Biology and dynamics in the non-endemic area of Antananarivo. Arch Inst Pasteur Madagascar. 1978;46(1):241-69.

40. Rollinson D, Knopp S, Levitz S, Stothard JR, Tchuem Tchuente LA, Garba A, Mohammed KA, Schur N, Person B, Colley DG, et al. Time to set the agenda for schistosomiasis elimination. Acta Trop. 2013;128(2):423-40.

41. Rasoamanamihaja CF, Rahetilahy AM, Ranjatoarivony B, Dhanani N, Andriamaro L, Andrianarisoa SH, Jourdan PM. Baseline prevalence and intensity of schistosomiasis at sentinel sites in Madagascar: informing a national control strategy. Parasit Vectors. 2016;9:50.

42. Spencer SA, Penney J, Russell HJ, Howe AP, Linder C, Rakotomampianina ALD, Nandimbiniaina AM, Squire SB, Stothard JR, Bustinduy AL, et al. High burden of Schistosoma mansoni infection in school-aged children in Marolambo District, Madagascar. Parasit Vectors. 2017;10(1):307.

43. Breuil J, Moyroud J, Coulanges P. Elements of the ecologic antibilharziosis campaign in Madagascar. Arch Inst Pasteur Madagascar. 1982;50(1):131-44

44. Hofkin BV, Mkoji GM, Koech DK, Loker ES. Control of schistosometransmitting snails in Kenya by the North American crayfish Procambarus clarkii. Am J Trop Med Hyg. 1991;45(3):339-44.

45. Savaya Alkalay A, Rosen O, Sokolow SH, Faye YP, Faye DS, Aflalo ED, Jouanard N, Zilberg D, Huttinger E, Sagi A. The prawn Macrobrachium vollenhovenii in the Senegal River basin: towards sustainable restocking of all-male populations for biological control of schistosomiasis. PLoS Negl Trop Dis. 2014;8(8):e3060.

46. Ministry of Agriculture LaF. Arrété No 16 825/2008. Madagascar: Ministry of Agriculture LaF; 2008.

47. Westphal MI, Browne M, MacKinnon K, Noble I. The link between international trade and the global distribution of invasive alien species. Biol Invasions. 2008;10(4):391-8.

48. Schatz GE. Endemism in the Malagasy tree flora. In: Lourenco WR, Goodman SM, editors. Diversity and endemism in Madagascar. Paris: ORSTOM; 2000. p. 1-17.

49. Vrålstad T, Knutsen AK, Tengs S. A quantitative TaqMan MGB real-time polymerase chain reaction based assay for detection of the causative agent of crayfish plague Aphanomyces astaci. Vet Microbiol. 2009;137:146-55.

50. Strand DA. Environmental DNA monitoring of the alien crayfish plague pathogen Aphanomyces astaci in freshwater systems. Oslo: University of Oslo; 2013.
Ready to submit your research? Choose BMC and benefit from:

- fast, convenient online submission

- thorough peer review by experienced researchers in your field

- rapid publication on acceptance

- support for research data, including large and complex data types

- gold Open Access which fosters wider collaboration and increased citations

- maximum visibility for your research: over 100M website views per year

At $\mathrm{BMC}$, research is always in progress.

Learn more biomedcentral.com/submissions 